\title{
Influence of the Administrative Services Quality on the Public Satisfaction in the Land Certificate Program at the National Land Agency (BPN) of Tangerang City
}

\author{
Nafizha Trie Permata Sari ${ }^{1}{ }^{*}$ Siti Rochmah ${ }^{2}$, Mochamad Chazienul Ulum ${ }^{3}$ \\ ${ }^{1,2,3}$ Faculty of Administrative Science, Brawijaya University, Malang, Indonesia \\ Email: nafizha3@student.ub.ac.id
}

\begin{abstract}
Many problems arise in the public services provided by the National Land Agency (BPN) of Tangerang City to administer public land certificates. The topic raised in this research is public service at the National Land Agency of Tangerang City. The essence of the vision of public service is the realization of excellent public services, which means realizing public satisfaction to get services from government agencies. A high level of public satisfaction is a sign that an organization is successfully performing its core tasks and functions. This study was carried out to examine the influence of service quality (reliability, responsiveness, assurance, empathy and tangible) towards public satisfaction. This research used a quantitative study, a data collection technique derived from surveys, observations, and documentation. The method used to determine the sample size in this study uses the Slovin formula with a margin of error of $10 \%$, so 115 samples are taken from the 1015 population of the Tangerang population using the BPN Tangerang service. While data analysis using descriptive statistical analysis and multiple linear regression analysis to test our research hypotheses. The results of this study indicate that if tested simultaneous, the dimensions of service quality influence on public satisfaction. Meanwhile partially, reliable and tangible influence the public satisfaction and the responsiveness, assurance, empathy has rejected to influence the public satisfaction.
\end{abstract}

Keywords: Administrative Services Quality, Land Certificate, Public Satisfaction, Quality.

\section{INTRODUCTION}

The government must produce goods and services that are economical, effective, efficient, and accountable to all people in need [1]. The provision of public services to the people by government officials is indicative of the functioning of the state apparatus as officials. In an increasingly critical society, the public bureaucracy requires changing its position and role in providing public services [2]. From those who like to govern and command, they change to those who like to serve. Those who like to use a power approach change to those who like to help without being discriminatory. Public service [3] provides services to a person or public interested in the organization by the basic rules and procedures. Then, understand everything related to the service so that the people who receive it are satisfied with the service provided. Service apparatus must be more proactive in observing the new service paradigm so that the services provided have high competitiveness in various public activities [4]. The government as a public service provider is increasingly required to create good and very high-quality services, to encourage and improve the public's welfare [5].

The research at the Tangerang National Land Agency (BPN) office has the task of carrying out government duties in the land sector by the provisions of the legislation. The National Land Agency (BPN) [6] was formerly known as the Agrarian Office. The National Land Agency (BPN) regulates through Presidential Regulation Number 20 of 2015. Currently, based from researcher's field observations at the National Land Agency (BPN) of Tangerang City, the officers who provide services to the public are not by the quality of service provided by the public service provider. Judging from the various service problems that exist at the BPN Tangerang office, such as the length of handling of cerfiticate files, the length of readiness for certificate with a minimum of six months, the unfriendliness of the employees, lack of cooperation and responsibility, also solutions that are not according to the SOP. All these problems include the dimensions of service quality. Because currently, consumer satisfaction is the primary measure of public services, service quality in business, 
management, and bureaucracy. Customer satisfaction [7] has become a focus of attention in business and management to be considered a key criterion in various business and organizational management literature for both commercial and non-profit organizations.. Customer satisfaction [8] is moving towards state bureaucracy in the context of public services. Because, as the end of all bureaucratic reforms, it is very important to improve the quality of public services [9]. Therefore, public services provided by the public sector are still unsatisfactory to the public. Public services carried out by the bureaucracy do not serve customers but serve citizens [10].

Therefore, the purpose of this study is to see the influence of service quality on public service on the satisfaction of the population in BPN Tangerang office, regarding service delivery whether the services provided are by public expectations or not. there should be quality, and there are dimensions of service quality, including responsiveness, reliability, assurance, empathy, tangibles, where these five dimensions become benchmarks in providing services by related parties as public service providers.

\section{LITERATURE REVIEW}

In this section, literature review plays an important role in research as it can provide direction for the research itself. The literature review describes previous studies related to similar problems, and the theoretical shell is the theoretical framework that supports the researcher's thinking.

\subsection{Public Services}

Public services defined by Sinambela [11] as the provision of services, meeting the needs of individuals or communities interested in an organization according to established basic rules and procedures. Another definition according to Rahmayanty [12] public services are all activities whose fulfillment must be guaranteed, regulated, and supervised by the government because they are necessary for realizing and developing social interdependence. In essence, its realization is challenging to implement without the intervention of government forces.

As a result, public services serve or meet the needs of those interested in the organization or the public, subject to basic rules and procedures. According to 63/KEP/M.PAN/7/2003, a public service is any service provided by the public service administration to meet the needs of service beneficiaries and to comply with legal regulations. [11].

The company's quality of service is certainly not just about satisfaction. According to Zeithaml, Parasuraman \& Berry service quality can can be measured in five dimensions: assurance, reliability, responsiveness, tangibles, and empathy [13].

\subsection{Public Satisfaction}

Satisfaction or dissatisfaction is an individual's feelings of joy or disappointment that arise when an impression of actual or actual product performance is compared with expected product performance [12],[14].

Consumers who are satisfied with the products or services purchased and used will return to using the products offered. Meanwhile, according to Kotler satisfaction is the extent to which a product level is perceived by buyer expectations. Consumer satisfaction is defined as a product by the reality accepted by consumers. Consumer satisfaction is measured by how well consumer expectations for a product or service match product performance and those expectations [15].

The public as consumers as well as customers will feel satisfied if the service performance on public services, they get is the same or exceeds their expectations and vice versa. Based on what has been described and explained above, public satisfaction is a level of feeling that arises because of service performance in public services obtained by the public after comparing with what is expected. According to Rahmayanty [12] there are several indicators of public satisfaction, such as procedures, service requirements, clarity of service personnel, discipline of service personnel, responsibility of service personnel, competence of service personnel, speed of service.

\subsection{Previous Research}

Based on research from Salim [16] in his research entitled "Customer Satisfaction (Public Satisfaction) On Services In Administrative Village Office" with the Structural Equation Model method, the results obtained that the tangible, reliability, responsiveness, empathy and assurance individually affect public satisfaction.

The results of this study are in line with previous research conducted by Nilwala [17] entitled "The Effect of Service Quality on Satisfaction apropos Service Recipients of Divisional Secretariats in Colombo District in Sri Lanka" shows that the dimensions of service quality include reliability, assurance, tangible, empathy, and responsiveness significantly affect public satisfaction.

\subsection{Research Model and Hypothesis}

Every government employee as a service provider is required to provide suitable work results from work. So that the government can provide the results of their work to the public through services provided in the form of 
quality services that have dimensions of responsiveness, reliability, assurance, empathy, and tangibles where these five dimensions become benchmarks in providing quality services BPN Tangerang, thus, the public can directly assess whether the services provided are by the wishes and expectations of the public. By the concept that has describe, the model in this research shown in figure 1.

Figure 1 Research Model

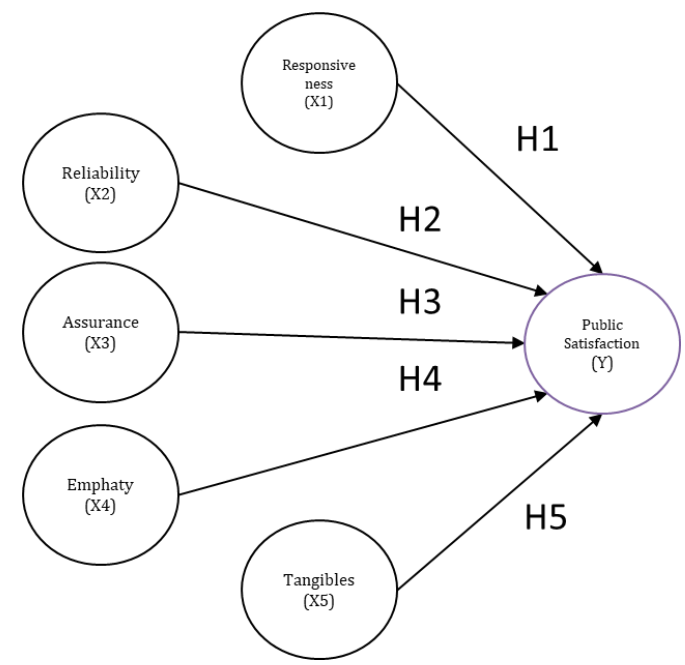

Figure 1 describes the model used in this study, and the independent and dependent variables for generating a hypothesis in this study. A hypothesis is a statement that describes the relationship between two case-by-case variables, is an ad hoc assumption that requires that a statement in a study be tested for truth or false, and that has an advantage in order for the research process to be effective and efficient [18]. The following five hypotheses in this research:

H1: There is an influence of Responsiveness on Public Satisfaction

$\mathrm{H} 2$ : There is an influence of Reliability on Public Satisfaction

H3: There is an influence of Assurance on Public Satisfaction

H4: There is an influence of Empathy on Public Satisfaction

H5: There is an influence of Tangibles on Public Satisfaction

\subsection{Variable Operationalization}

According to Aritonang [19], the notion of variable operationalization is research containing all activities to obtain quantitative empirical data regarding variations in the characteristics of these variables; it is a specification of what is measured and how to measure it.
Table 1 Variable Operationalization

\begin{tabular}{|c|c|c|}
\hline Variable & Indicators & $\begin{array}{l}\text { Question } \\
\text { Points }\end{array}$ \\
\hline \multirow[t]{2}{*}{$\begin{array}{l}\text { Responsivene } \\
\text { ss } \\
\text { (X1) }\end{array}$} & $\begin{array}{l}\text { 1. Response of } \\
\text { Officers to } \\
\text { Complaints }\end{array}$ & $1,2,3$ \\
\hline & $\begin{array}{l}\text { 2. Response of service } \\
\text { personnel to suggestions and } \\
\text { criticism }\end{array}$ & $4,5,6,7$ \\
\hline \multirow[t]{2}{*}{$\begin{array}{l}\text { Reability } \\
\text { (X2) }\end{array}$} & $\begin{array}{l}\text { 1. Reliability of Officers in } \\
\text { Providing } \\
\text { Information. }\end{array}$ & $8,9,10$ \\
\hline & $\begin{array}{l}\text { 2. Reliability of Officers in } \\
\text { Carrying Out Service } \\
\text { Procedures } \\
\text { Technicalities }\end{array}$ & $11,12,13$ \\
\hline \multirow[t]{2}{*}{$\begin{array}{l}\text { Assurance } \\
\text { (X3) }\end{array}$} & $\begin{array}{l}\text { 1. Administrative and } \\
\text { Technical Capabilities of } \\
\text { Service Officers }\end{array}$ & $\begin{array}{l}14,15,16,1 \\
7\end{array}$ \\
\hline & $\begin{array}{l}\text { 2. Officers guarantee } \\
\text { punctuality, cost certainty } \\
\text { and legality in services }\end{array}$ & $18,19,20$ \\
\hline \multirow[t]{2}{*}{$\begin{array}{l}\text { Empathy } \\
\text { (X4) }\end{array}$} & $\begin{array}{l}\text { 1. Attention of Service } \\
\text { Personnel }\end{array}$ & $21,22,23$ \\
\hline & $\begin{array}{l}\text { 2. Care and Hospitality of } \\
\text { Service Personnel }\end{array}$ & $\begin{array}{l}24,25,26,2 \\
7\end{array}$ \\
\hline \multirow[t]{2}{*}{$\begin{array}{l}\text { Tangibles } \\
\text { (X5) }\end{array}$} & $\begin{array}{l}\text { 1. Waiting room/office and } \\
\text { service equipment }\end{array}$ & $28,29,30$ \\
\hline & $\begin{array}{l}\text { 2. Appearance of Service } \\
\text { Personnel. }\end{array}$ & 31,32 \\
\hline \multirow{7}{*}{$\begin{array}{l}\text { Public } \\
\text { Satisfaction } \\
\text { (Y) }\end{array}$} & 1. Service Procedures & 33 \\
\hline & 2. Service Requirements & 34,35 \\
\hline & $\begin{array}{l}\text { 3. Clarity of Service } \\
\text { Personnel }\end{array}$ & 36,37 \\
\hline & $\begin{array}{l}\text { 4. Discipline of Service } \\
\text { Officers }\end{array}$ & 38,39 \\
\hline & $\begin{array}{lrr}5 . & \text { Service } & \text { Officer's } \\
\text { responsibilities } & \\
\end{array}$ & 40,41 \\
\hline & 6. Service personnel's ability & 42,43 \\
\hline & 7. Speed of Service & 44,45 \\
\hline
\end{tabular}

Table 1 explains that there are dependent and independent variables, each of which has indicators. The indicator is a question in the questionnaire given to the respondents, then 45 questions need to be answered to get the public's perception of the variables posed in the form of questions.

\section{METHOD}

The type of study is a quantitative study. According to Zacharias [20] the quantitative method is a traditional method that has been used for a long time that it has become a tradition as a method for research. Quantitative methods are scientific because they meet concrete, objective, measurable, rational, and systematic scientific principles. Quantitative methods are discovery methods because they allow us to discover and develop a variety 
of new science and technology. This method is a quantitative method because the survey data is in the form of numbers and the analysis uses statistics [18].

\subsection{Population and sample}

The research population is taken from people who have used services at BPN Tangerang for land certificates in the government program called Program Tanah Kota Lengkap (PTKL) totaling 1015 populations from June to August 2021.

In this research using purposive sampling method. Purposive sampling is by taking samples from the population based on specific criteria. Then, the sample in this research using the slovin technique using a tolerance value of $10 \%$, so that 115 samples obtain as respondents.

\subsection{Data collection}

According to Sugiyono [21], Data collection technology is the most important step in research, as the main purpose of research is to acquire data. If the researcher is not familiar with data collection technology, the researcher will not be able to obtain standardcompliant data. To retrieve the data, the author uses the following data collection techniques:

\section{a. Questionnaire}

A questionnaire is a data collection conducted with the consent of the respondents to answer their written questions. This survey is an efficient data collection method if the researcher is confident about the variables being measured and what to expect from the respondents.

\section{b. Documentation}

Documentation means obtaining data directly from the research facility, including related books, regulations, activity reports, photographs, and related research datadocumentation of research based on the location of BPN Tangerang.

\subsection{Analysis Technique}

According Sugiyono [1] in quantitative research, data analysis techniques are activities after data has been collected from all respondents or other data sources. The data analysis activities are as follows:

a. Grouping data by variable and respondent type,

b. Aggregate data based on variables from all respondents,

c. Presentation of data for each variable examined,

d. Performing calculations to answer the problem formulation,

e. Perform calculations to test the proposed hypotheses.
The study was conducted using a questionnaire and was rated on a 1 to 5 scale (1=strongly disagree, $2=$ disagree, $3=$ neutral, 4=agree, 5=strongly agree) using a Likert scale.

\subsubsection{Validity and Reliability}

A test is said to be valid if the test can measure intended to measure. According to Monecke [22] if the instrument is said to be valid, this means that the measuring used to retrieve the data is valid. Therefore, valid means that the instrument needs to measure what is being measured. Furthermore, according to Sugiyono [23], reliability is the same as consistency or constancy for reliability techniques. Survey tools are considered reliable, it has consistent results in measuring what is to be measured. The more reliable a test has requirements, the more confident we can say that the test results have the same results when repeated. In this research, the reliability test used Cronbach alpha because this instrument research used a questionnaire.

\subsubsection{Multiple Regression Analysis}

Regression analysis [24] is a useful statistical technique for examining and modeling relationships between variables. Multiple regression to solve a regression analysis that creates a relationship between two or more independent variables. The multiple model of the linear regression equation is:

$\mathrm{Y}^{\prime}=\mathrm{a}+\mathrm{b} 1 \mathrm{X} 1+\mathrm{b} 2 \mathrm{X} 2+\ldots . .+\mathrm{bnXn}$

in equation (1) $\mathrm{Y}^{\prime}$ is the predicted influence value, a is a constant or a price number $\mathrm{X}=0, \mathrm{~b}$ is a regression coefficient $X$ value of the dependent variable.

\subsubsection{Hypothesis Test}

In testing the hypothesis using three types of tests to answer the proposed hypothesis, namely the T-Test, FTest, and KD-Test, the following is the explanation.:

a. T-Test: Used to test one of the hypotheses in a study using multiple linear regression. T-test checks each variable in part. The result of the ttest parameter can be found in the coefficient table in the sig column. standard:

1) If the probability is $<0.05$, we can say that there is an influence between the independent variables and the partially dependent variable.

2) If the probability is $>0.05$, we can say that there is no influence between the independent variables on the partially dependent variable.

b. F-Test: At the same time, it determines the effect of the independent variable on the dependent variable. The results of the F-test parameters are in the ANOVA table in the sig column. With standard: 
1) If the probability value is $<0.05$, it can be said that there is a jointly significant influence between the independent variables on the dependent variable.

2) If the probability value is $>0.05$, there is no significant effect between the independent and dependent variables.

c. KD-Test: This test is intended to determine the percentage or percentage of total variation of the dependent variable described by the independent variable. If the analysis used is a simple regression, the decision coefficient value is used. However, if the analysis using is multiple regression, use the adjusted coefficient of determination.

\section{RESULT AND DISCUSSION}

This survey was conducted to understand the influence of the dimensions of service quality on public services on public satisfaction at the BPN Tangerang office. This study is experimental to find out how large the causal relationship and causal relationship were when the experimental group was given any treatment and the control group did not receive any treatment.

The data collected in this study consisted of several methods such as observation methods, test methods, and documentation methods. Researchers use observational methods to observe the conditions and services of BPN Tangerang. Researchers used the test method to determine people's perceptions of who received services at BPN Tangerang. At the same time, the documentation method is used to find out data on the state of BPN regarding the job duties and photos of the research results. Furthermore, the researcher conducted the statistical analysis with SPSS 25 [25] to determine how the causal relationship occurred between variables, whether the dimensions of service quality and public satisfaction at the BPN Tangerang office had a significant effect or not, then made a report on the results of the research.

\subsection{Validity and Reliability}

The results of validity testing, the questionnaire contains these six variables. There are 45 questions in the questionnaire, which 115 respondents have filled out in this study. One way to find out which questionnaires are valid, and which are invalid, we must first find out the $r$ table with the value of $\mathrm{r}$ table $=0.1569$. From the result of calculating the reliability, it can be seen that $r$ count $>$ $r$ table. All of the 45 questions are valid because the number $r$ is greater than the number $r$ in the table.

In addition, reliability testing makes sense to measure whether the questionnaires used in the survey to measure the effects of variables $\mathrm{X}$ and $\mathrm{Y}$ are consistent. Before the reliability test, we need a decision-making basis, an alpha of 0.60 . The Cronbach alpha value, a value of $0.738>$ 0.60 , and these results can be concluded that all statements on this variable are stated to be reliable or trustworthy.

\subsection{T-Test}

A t-test to determine the significant level of the regression coefficient when the significant regression coefficient individually indicates the degree of influence of the independent variable (explanation) on the description of the dependent variable.

Table 2 T-Test

\begin{tabular}{|c|c|c|c|c|c|}
\hline \multirow{2}{*}{ Model } & Unstdr & \multicolumn{2}{|c|}{ Stdr. } & \multirow{2}{*}{$\mathrm{t}$} & \multirow{2}{*}{ Sig. } \\
\cline { 2 - 4 } & $\mathrm{B}$ & Std. Error & Beta & & \\
\hline Constant & 19.267 & 3.956 & - & 4.870 & .000 \\
\hline $\mathrm{X} 1$ & .071 & .129 & .052 & .550 & .583 \\
\hline $\mathrm{X} 2$ & .364 & .135 & .237 & 2.693 & .008 \\
\hline $\mathrm{X} 3$ & .205 & .115 & .177 & 1.784 & .077 \\
\hline $\mathrm{X} 4$ & .335 & .160 & .234 & 2.099 & .038 \\
\hline $\mathrm{X} 5$ & .382 & .134 & .224 & 2.846 & .005 \\
\hline \multicolumn{7}{|c|}{ Source : Processed Data $(2021)$} & \\
\hline
\end{tabular}

Based on table 2, it is known that the t value is 0.550 , $2.693,1.784,2.099,2.846$ and the significance value is $0.583,0.0080 .077,0.038,0.005$. This value means that the data variance between the $t$ and significance values has the same homogenity. Therefore, as a basis for making decisions in an independent sample T-test, the following conclusions can be drawn:

a. H1: $\mathrm{t}$ value score is 0.550 and a significance score is $0.583>0.05$, it is concluded that the hypothesis rejected means that there is no influence of Responsiveness on Public Satisfaction.

b. $\mathrm{H} 2$ : $\mathrm{t}$ value score is 2.693 and a significance score is $0.008<0.05$, it is concluded that the hypothesis is accepted means that there is an influence of Relibiality on Public Satisfaction.

c. H3: t value score is 1.784 and a significance score is $0.077>0.05$, it is concluded that the hypothesis rejected means that there is no influence of Assurance s on Public Satisfaction.

d. H4: t value score is 2.099 and a significance score is $0.038>0.05$, it is concluded that the hypothesis rejected means that there is no influence of Empathy on Public Satisfaction.

e. H5: $\mathrm{t}$ value score is 2.846 and a significance score is $0.005<0.05$, it is concluded that the hypothesis is accepted means that there is an influence of Tangibles on Public Satisfaction. 


\subsection{F-Test}

$F$ test in ANOVA statistical testing is a form of hypothesis testing that can draw conclusions based on data or statistical groups. Decision making has seen from this test done by looking at the $\mathrm{F}$ value contained in the ANOVA table

Table 3 F-Test

\begin{tabular}{|c|c|c|}
\hline Model & F & Sig. \\
\hline Regression & 15.646 & $.000 \mathrm{~b}$ \\
\hline
\end{tabular}

Table 3 explains the $f$ value of this research of 15.646. Then the significance value of $0.000<0.05$, based on the determination of the significance F-test. The hypothesis is accepted if tested simultaneously on the all$\mathrm{X}$ variable to $\mathrm{Y}$.

\subsection{KD-Test}

The coefficient of determination for linear regression indicates the extent to which all independent variables can explain the variance of the dependent variable. Simply put, the coefficient of determination is calculated by squared the correlation coefficient $(\mathrm{R})$.

Table 4 KD-Test

\begin{tabular}{|c|c|c|c|}
\hline $\mathrm{R}$ & R Square & $\begin{array}{c}\text { Adjusted } \\
\text { R Square }\end{array}$ & $\begin{array}{c}\text { Std. Error of the } \\
\text { Estimate }\end{array}$ \\
\hline $.646 \mathrm{a}$ & .418 & .391 & 4.073 \\
\hline
\end{tabular}

Source : Processed Data (2021)

Based on table 4, the results from the table above, the value of $\mathrm{R}$ as the correlation coefficient is 0.646 , while its know that $\mathrm{R}$ square as the coefficient of determination is 0.418 . These results can show how much influence the independent variable has on the ups and downs of the dependent variable. It explained that the independent variable has $41.8 \%$ in explaining the variance of the dependent variable, and there is still $58.2 \%$ of the variance explained by other dependent variable factors.

If tested simultaneously with the F Test shows the results are in accordance with the study of Nilwala [17] in which service quality influence public satisfaction, means that the higher the quality of service, the higher the public satisfaction. Whereas the aspects of service quality taken partially by $\mathrm{T}$ Test show that only the tangible and reliability have an influence on public satisfaction, while responsiveness, assurance, and empathy has rejected to influence the public satisfaction. This result is different from research conducted by Salim [16] that the tangible, reliability, responsiveness, empathy and assurance if tested partially affect public satisfaction. Variables such as responsiveness, assurance and empathy are related to human resource skills, where officers are less able to respond to the public, provide a sense of security and cannot understand what the public needs.

\section{CONCLUSIONS}

The conclusions in this research are if tested simultaneously, there is significant influence between service quality variables such as responsiveness, reliability, assurance, empathy, and tangibles, on the public satisfaction. If tested partially, the hypotheses proposed to test the influence of service quality dimensions on public satisfaction, namely $\mathrm{H} 1$ is rejected, $\mathrm{H} 2$ accepted, $\mathrm{H} 3$ rejected, $\mathrm{H} 4$ rejected, and $\mathrm{H} 5$ accepted. Also the value of R2 states that there are still $58.2 \%$ of other factors to support public satisfaction, especially in measuring satisfaction

From the results of the research conducted, there are variables of service quality that are not optimal at the BPN Tangerang so that these variables rejected the influence on public satisfaction, these variables are responsiveness, assurance and empathy. The solution to overcome the problem of service quality to public satisfaction is based on the managerial function of human resources, the management can supervise and also increase the capacity of the personnel (officers), so they can be more responsive, caring and give more attention to the public.

\section{RESEARCH LIMITATIONS}

This research have limitation such as only six variables used and the variable has used based on report from people of Tangerang who have used services of BPN Tangerang and on the other hand, further research is needed on the BPN Tangerang officers to see the other factors that influence public satisfaction such as organizational commitment and leadership style in similar government agencies.

\section{ACKNOWLEDGMENTS}

In this research, the authors thank the BPN Tangerang, who have provided the author with the opportunity to obtain information about the procedures and workings of this agency, whose hope is to improve the services provided by BPN to the public.

\section{REFERENCES}

[1] J. Mishra and V. Attri, "Governance, Public Service Delivery and Trust in Government," Stud. Indian Polit., vol. 8, no. 2, pp. 186-202, Dec. 2020, doi: 10.1177/2321023020963518.

[2] Q. Hu, L. Zhang, W. Zhang, and S. Zhang, "Empirical Study on the Evaluation Model of Public Satisfaction With Local Government Budget Transparency: A Case From China," SAGE Open, vol. 10, no. 2, p. 215824402092406 , 
Apr. 2020, doi: 10.1177/2158244020924064.

[3] H. A. Hassan, X. Zhang, A. B. Ahmad, and B. Liu, "Public Service Motivation and Employee Change-Supportive Intention: Utilizing the Theory of Planned Behavior," Public Pers. Manage., vol. 50, no. 2, pp. 283-304, Jun. 2021, doi: $10.1177 / 0091026020934515$.

[4] M. Rusli and M. Yahya, "Analysis of the Influence of Leadership Style and Work Environment on Apparatus Performance in Improving Service Quality,” pp. 3169-3177, 2021.

[5] N. Hendren and B. Sprung-Keyser, "A Unified Welfare Analysis of Government Policies*," $Q$. J. Econ., vol. 135, no. 3, pp. 1209-1318, Aug. 2020, doi: 10.1093/qje/qjaa006.

[6] D. Iskandar, S. M. Janah, and A. Syaifudin, "COMPUTERIZED APPLICATION LOC (LAND OFFICE COMPUTERIZATION) AT THE NATIONAL LAND AGENCY FOR LAND CERTIFICATION SERVICE QUALITY," Incomtech, vol. 8, no. 2, pp. 63-68, 2019.

[7] I. Ranggadara, G. Wang, and E. R. Kaburuan, "Applying Customer Loyalty Classification with RFM and Naïve Bayes for Better Decision Making," in 2019 International Seminar on Application for Technology of Information and Communication (iSemantic), Sep. 2019, pp. 564568, doi: 10.1109/ISEMANTIC.2019.8884262.

[8] P. Mathangani and I. Sile, "Customer Care Strategies On Customer Satisfaction In Government Agencies: A Case Study Of Kenya Bureau Of Standards (Kebs)," Eur. J. Manag. Mark. Stud., vol. 5, no. 4, pp. 113-129, 2020.

[9] Hadian, D, "The Relationship Organizational Culture and Organizational Commitment on Public Service Quality; Perspective Local Government in Bandung, Indonesia," Int. Rev. Manag. Mark., vol. 7 number 1, no. 1, pp. 230237, 2017.

[10] Y. Li and H. Shang, "Service quality, perceived value, and citizens' continuous-use intention regarding e-government: Empirical evidence from China," Inf. Manag., vol. 57, no. 3, p. 103197, Apr. 2020, doi: 10.1016/j.im.2019.103197.

[11] L. Sinambela, Reformasi Pelayanan Publik: Teori, kebijakan, dan implementasi. Jakarta: Bumi Aksara, 2012.

[12] N. Rahmayanty, Manajemen Pelayanan Prima. Yogyakarta: Graha Ilmu, 2013.

[13] V. A. Zeithaml, How do you measure service quality. Mapping Out Marketing: Navigation Lessons from the Ivory Trenches. New York: Routledge, 2018.

[14] M. Ansari, "Affect of Service Quality , Trust , and Image toward Value and Public Satisfaction on Administration System Office Makassar City," vol. III, no. Xi, pp. 1-13, 2015.
[15] V. A. Zeithaml, Services marketing: Integrating customer focus across the firm. New York: McGraw-hill, 2013.

[16] M. Salim, S. Bachri, and M. R. Febliansa, "Customer Satısfaction (Public Satısfaction) on Services in Admınıstratıve Village Office," Asia Pacific Manag. Bus. Appl., vol. 007, no. 01, pp. 17-30, 2018, doi: 10.21776/ub.apmba.2018.007.01.2.

[17] N. Nilwala, "The Effect of Service Quality on Satisfaction Apropos Service Recipients of Divisional Secretariats in Colombo District in Sri Lanka," SSRN Electron. J., pp. 968-987, 2017, doi: 10.2139/ssrn.2909729.

[18] Sugiyono, Metode Penelitian Kuantitatif, Kualitatif dan $R \& D$. Bandung: Alfabeta, 2011.

[19] L. R. Aritonang, Riset Pemasaran. Bogor: Ghalia Indonesia, 2007.

[20] T. Zacharias, Metode Penelitian Sosial Teori dan Aplikasi. Kabupaten Ponorogo: Uwais Inspirasi Indonesia, 2019.

[21] Sugiyono, Metode Penelitian Kuantitatif, Kualitatif, Dan Kombinasi (Mixed Methods), 4th ed. Bandung: Alfabeta, 2013.

[22] A. Monecke and F. Leisch, "semPLS: Structural Equation Modeling Using Partial Least Squares," J. Stat. Softw., vol. 48, no. 3, pp. 1-32, 2012.

[23] Sugiyono, Metode Penelitian Administrasi. Bandung: CV Alfabeta, 2002.

[24] Ridwan, Skala Pengukuran Variabel-Variabel Penelitian. Bandung: Alfabeta, 2002.

[25] J. O. Aldrich, Using IBM SPSS statistics: An interactive hands-on approach. New York: Sage Publications, 2018. 